\title{
Political Practice of Multiculturalism in Bali; Case Study of Kusamba and Village of Java
}

\author{
Bandiyah \\ Departement of Political Sciences, Udayana University Bali, Indonesia \\ dyah_3981@yahoo.co.id
}

\begin{abstract}
One of harmony life of the nation is to build a multicultural values of social interaction in the community. Issue of religion, ethnicity is often the cause of conflict and social tensions in Indonesian society. This study was about to lift a cult people of Bali are in caring for and maintaining the values of harmony of life as the practice of multiculturalism that is still awake. Kusamba and Java Village (Kepaon) are the two areas that will be elaborated and be a role model of pilot local wisdom that still survive in Indonesia. Extracting data using qualitative methods with direct observation in the field and in-depth interview some of the main and reliable sources. This study explains that the practice of multiculturalism in society Kusamba is influenced by the values instilled in the kingdom of Gelgel Klungkung which can accommodate the interests of the parties between immigrants and natives with the wise and prudent. In the end, migrant communities have a brotherhood with indigenous communities and instead they fought together against colonialism. While the values of multiculturalism in Java Village formed because of cultural migration followed by building strong social systems through tolerance and upholds the value of pluralism in society.
\end{abstract}

Keywords: Practical of multiculturalism, Kusamba, java Village, Klungkung kingdom, Bali

\section{INTRODUCTION}

Indonesia when the period of the New Order regime in power, management of diversity seemed to have harmony between different groups in terms of customs, culture, religion, language, immigrants or natives. Consciously government to manage and control this diversity into order and harmony that can support economic development. But in reality, strict controls to manage the harmony has led to many problems. One is SARA (tribal religions, races and groups). Dictum is that ethnicity, religion, race and class are the most prominent source of diversity and be sensitive matters and should be treated with caution, should not be touched because it will cause a certain group anger. Therefore the whole discourse is limited.

What is interesting after the collapse of the New Order, was triggered by a popular movement of reform, this paradigm seems to have not changed too much. There is room for greater diversity, but with clear restrictions. The presence of the reforms at least give space to freedom of expression which is much broader decentralization policy to reduce the powers of the central government and regional authorities recognize that much greater. Space comprehensive expression giving way for new groups as well as those that had been repressed during the New Order to perform more freely, making more visible their religious identity or strengthening of the customs and cultures.

After the reform era echoed appear localising power to borrow fill of Vedi Hadiz (2010) is a process spread of the locus of power from the center to the regions that have consequences on the opening of political spaces at the local level. In the political space opened, various actors have interests ideological, political, or economic, interact, negotiate or even compete for the public space. Thereby localising the ongoing power opens opportunities for the renegotiation process of public space. Power relation between the strength of local questionable and sued back. In the context of local politics in Indonesia, it was expressed in the renegotiation process territorialising political phenomenon. Political territorialising is a strategy undertaken by individuals or groups to influence and control of an area and subsequently gave signs and characters on the region as a region of power.

In Bali, the process of character on the region's already been done on the project Baliseering colonial rule (Bali for Bali). Bali discourse to give birth to the political reorganization of local government in two levels; strengthening the indigenous village as a 
stronghold of Hindu and restore the power of the kings as bestuurders country. The form of local authority reorganization carried out in the framework of the colonial political interests at that time the nationalist movement and counter act the expansion of Islamic radicalism that time developing in Java (Parimantra:2004)

In the process of localization of power, politics teritorialisme resurfaced, is evident is the politics of identity, which is placed as a bastion of Hindu customs, steady Bali discourse popularized. In such a context, where the public space for others religion? What happened in the middle of the process of this territorialising. Bali island is not completely homogenous and sealed. According to the historical perspective, already hundred of years immigrants from Bali, both from Bugis, Banjar and Javanese visiting and living in Bali. The question that arises is whether they have the container in a joint arrangement or a shared community spaces, including social institutions in their communities.

This study will explore Kampung Jawa and Kampung Kusamba as two cultural entities Muslims who live in our communities and localities power in the fortress of Hinduism. Both areas have been selected for being the hometown of an open and dynamic shows that the residents in Kampung Islam has a space of autonomy to organize itself in the form of village government. In practice the government in Bali, the village was given a position as village offices. So by giving a position as village offices, the Muslims in the village the right to choose their own leaders, set up business together in village regulations, as well as administrative or service obtained as villages other agencies in Bali. While the traditional village (Pakraman) regulate all matters relating to indigenous culture and Hindu religion. Both this government work in harmony without their overlapping powers or program activities. This is one comfort room in a bag autonomy minority community that was formed through a dual governance in Bali.

However, how these communities interact in space and larger affairs, for example in managing the system of government, to manage the values of multiculturalism that social harmonization materialize. Due to limited, this study will be focused towards multicultural how two different entities manage and maintain those values.

\section{METHODS}

\section{Types of Research}

This study was conducted with a qualitative descriptive approach which describe how the practice of social politics happens by looking for values that are built in the context of reality and background to construct the phenomenon. To achieve the expected goals, this study will be conducted in two phases, namely: (a). Pre-study phase (Desk Study). In the pre-study phase, the activities undertaken are mapped the problem, field observation and internal discussions, photographing information data results of previous research. At this stage, will contribute important input to the next stage; (B). Field research phase. To obtain a complete data depth interviews were conducted primary resource persons were elected as follows:

Table 1.

\section{Informant Interviews}

\begin{tabular}{|l|l|l|}
\hline No & Interviewees & Institution \\
\hline 1. & Ida Bagus Satijajaya & Head of Desa Kusamba \\
\hline 2. & Hambali & $\begin{array}{l}\text { Head of Kampung Islam } \\
\text { Kusamba }\end{array}$ \\
\hline 3. & Haji Mugni & $\begin{array}{l}\text { Public Pigure Kampung } \\
\text { Islam Kusamba }\end{array}$ \\
\hline 4. & Sutikno Wijaya & Head of Kampung Jawa \\
\hline 5. & H. Misbahul Munir & $\begin{array}{l}\text { Public pigure Java } \\
\text { Village (GPA; Young } \\
\text { Ansor Movement of Bali) }\end{array}$ \\
\hline
\end{tabular}

\section{Types and Sources of Data}

This study uses primary and secondary data. Primary data is derived from key informants were conducted through interviews. Secondly, it is done with the secondary data analysis of a wide range of literature review, research results, discussion and so forth.

\section{Analysis of Data}

The research data is done through a number of analysis: first, the reduction of data with sorting, concentration of attention, simplification, transformation of raw data that emerged from the written records on the field. Second, the presentation of data by presenting a set of structured information that gives the possibility of drawing conclusions and taking action or simplification of information. Third, draw the conclusion that the configuration activities of the whole or a review of the record in the field, the testing of the correctness and validity of the data that appear on the sites. Once you have a solid foundation, strong conclusion and to be more detailed so that a final conclusion. 


\section{RESULT AND DISCUSSION}

\section{A. Practice of Daily Life Politics and Multikulturalisme in Java Village.}

Kampung Jawa called Wanasari hamlet is a village located in the Village Dauh Puri Kaja Denpasar. Most people in this village are the Madura. Actually, according to local people want to call as Kampung Madura. But because Madura located in East Java, the Java most appropriate term used for the name of the village. Based on population data (BPS Bali: 2015) Hamlet Wanasari population totaled 1705 households and has 8 Neighborhood (RT). The population of Kampung Jawa is 7699 inhabitants with a predominantly Muslim community.

Civilization began in the village of Java acceleration kingdom led by Cokorda to 10 have recourse to the Kingdom of Bangkalan Madura in order to join forces to fight together against colonialism in the 19th century Then came the war which ended with a victory for the Kingdom of acceleration. After the war, soldiers of Bangkalan given two choices; Bangkalan return to or remain in the area of Denpasar. For those who choose to live in Bali (Denpasar) is given the chance to settle and stay around Puri acceleration (about Pasar Badung). But along the way to experience discomfort among soldiers as a group of migrants and local residents of different cultures and customs so that the soldier settlers moved in Wanasari Regions is now known as Kampung Jawa. (Interviews with the management of the Youth Movement Ansor Bali Region: Misbahul Munir)

Beginning in the 1900s, the area Wanasari still a jungle overgrown with shrubs and weeds. Muslim migrants from Java, formerly doing business and trade activities in the area of Pasar Badung. The newcomers choose to live and settle around Badung market. In 1912, the royal government to renovate Badung market, and asked the settlers to occupies an area now called Wanasari hamlets or villages of Java. The migrants from Java and Madura in groups eventually moved there. Ethnic Bugis migrants are choosing to stay in the area Kepaon and Serangan. Java village area are still cleared shrubs began slowly and built housing. The land was a grant from the King of Badung and headmen endorsed by the King of Badung. The village head came from the Madura ethnic ethnicity dominates. In addition to Java and Madura ethnic, Kampung Jawa is also home of urbanization citizens Karangasem regency after the eruption of Mount Agung in 1963. Residents of Java village known a tradition of mutual ngejot ins and tradition, as a form of tolerance to environmental banjo and Balinese Hindus. The tradition is a tradition of mutual ins Muslims and Hindu Bali banjar engage in social activities. Tradition ngejot is silahturahmi activities between Muslims and Hindu Bali.

Javanese villagers become synonymous with the Muslim community in the city of Denpasar. Its existence can't be separated from the arrival of the urban. Based on observations in this study, Muslims from the village of Java are native who was born in the village of Java, as well as residents of urban migrants who end up staying and settling in the village of Java. Javanese village of Muslim indigenous communities are integrated with urban newcomers then created by a cross cutting Affiliations process, or the process of crossbreeding. According Nasikun (2004: 86), the integration of people in a social unit will increase the attachment, then cross cutting Affiliations can minimize conflicts that arise from the feared social plurality. Based on the findings, there are similarities and differences of the indigenous Muslim kampong of Java with urban Muslim immigrants. Similarities and differences are crossed and integrated in an attachment and identity as a Muslim villages in Java or cross cutting process Affiliations of Muslim Javanese village.

In the village of civilization Wanasari be capable of semi-autonomous village-run by migrants mainly from the Madura and the village has its own privileges. First, Wanasari village is a village official in Bali village government and its apparatus managed by the Javanese and Madura. Second, the privilege in the provision of space organization of activities of worship and religion without conflict sara group of Hinduism. For example Kampong Java Residents can turn the sound all day Adhan and study freely without intimidation by other religious groups. It is certainly different from the other villages in places, if a village's Muslim minority communities and mixed with Hindu majority and then the activities of practicing Muslims is limited and often lead to conflict. But not for long Kampong Java built by the system and the structure of village governance backed by Javanese making it easier management religious and other activities with autonomous.

Although Kampong Java community is given an autonomous and freedom in managing the village government, but is limited in accessing the activities at the level of local government. For Bali Local Government and District / City more 
dominated by local residents Hindu. This of course has implications for the lack of access to support and concern of local governments in the construction material in the Village Wanasari Dauh Puri Kaja village. However great the residents of Kampung Java do not complain and remain silent with these issues because of the cult of Kampung Java able to mobilize other Muslim communities outside Kampong Java region to help become donors in the name of brotherly co-religionists. For example, building houses of worship such as a mosque in Kampong Java can be done easily and quickly with the ease of the process with the permission of the local government and indigenous villages in Bali. this is different from the conditions in place in other places.

According to the public perception that brotherhood Kampung java who has nurtured since time becomes more important than questioning the government's minimal material assistance in the construction of the Village Wanasari. Although the Society Kampung Java Bali assumes that people are basically very receptive to migrant communities, but these communities must follow the rules established by the local government. This is in accordance with the philosophy houses Balinese people who do not have the gate signifies as a form of openness in accepting any kind including immigrant communities. The important thing is not to insult Hindu religion and customs and traditions as fraternal relations very highly regarded by the Balinese people irrespective of differences of religion and culture.

Planting the values of brotherhood and multiculturalism has brought the harmonious relationship between indigenous peoples and migrants (urban) to the present. Both people has nyamabraya principles that maintain mutual brotherhood. This is reflected in the following activities. For example on the day of Nyepi Muslims in Kampong Java, helped the success of the activities Nyepi example by not voicing azan, be energy security and pecalang in each activity of Hindu ceremonies, mutual aid in the cremation ceremony or wedding as well as other activities.

Vice versa, Hindus also mutual respect and participate instrumental in helping the environment held religious activities at Muslims. For example, when Eid Hindus helped provide employment for Muslim prayer as well as a security force for curb these activities. In organizing religious activities no one was harassed and disrupted because of their philosophy of life already made an impression on the hearts to each other and keep the feeling of brotherhood. At the end of civilization Barometer Muslims in Indonesia can be seen in Bali, This is the best of civilization religious communities in Denpasar.

\section{B. Practice of Daily Life Politics and Multikulturalisme in Kusamba Village}

Kusamba is the name of a village located in Klungkung regency of Bali. The region is divided into two parts. The first area is called the Village Kusamba that most people are Hindu, while the second area is called Kampung Kusamba, the majority of the people are Muslims. Although it is still in one region Kusamba, the Muslim community living in Kampung Kusamba has a system of self-government of autonomous administratively and given a position as village offices.

Muslim community in Kampung Kusamba still maintain the values to communicate using the Balinese language in everyday activities. Solidarity between the villagers and the Kampung Kusamba also seen in mutual cooperation activities at weddings, religious ceremonies, customs, national and so forth. Kampung Kusamba is keeping the values of multicultural since the first until now. Historically, the royal Gelgel as the oldest kingdom in the island of Bali never built a very good relationship with the Majapahit kingdom without any conflict at all. The concept of unity in diversity Tan harmony hana dharma Mangrwa developed to establish a balance of community life under the umbrella of the greatness of the king of Majapahit.

In constructing the balance there is a very important role performed by the Village Kusamba. Among others as the capital of the kingdom of Klungkung during the reign of Ida I Dewa Agung Putra Kusamba, both made palace close to the beach named Kusanegara. Third Kusamba be a historic place in the heroic events of the so-called war Kusamba became Klungkung community pride because in this war Dewa Agung Isteri Kanya had managed to kill General AV Michiels Dutch expedition leader who came to Bali in the 19th century In the kingdom of Klungkung, Kusamba has status as a foreign trade crossing area which was under the rule of King Gelgel and became the largest port and visited by traders from various countries and regions of the archipelago.

The settlers who crossed the Port Kusamba willing to settle then married to give birth to offspring and form a group of people with the 
name Kampung Kusamba. These communities, play an important role in commerce, business to be growing economy. In the political field the newcomers participate and help the kingdom Gelgel as a soldier in the war against colonialism. Caused such a great role, royal Gelgel reward by providing land and housing exclusively to immigrant communities.

The lives of immigrants who are in the minority Hindu majority neighborhood of course can lead to conflict and religious sara. But not so in Kusamba, two different public entities in indigenous cultures and religions is precisely mutual support and respect the religious activity that harmonization of inter-community relations can be maintained. In addition, at the time of the King of Klungkung kingdom Gelgel also play an active role in bridging and became a Muslim immigrant population mediation in case of conflict or social gap with Hindus. In this case the king plays fair and neutral. The royal role even been preserved until today, although the Klungkung kingdom had changed descent. Heritage of multicultural values built by the Royal Gelgel then was impression in the hearts of Hindu-Muslim communities, especially in areas Kusamba, therefore, not be surprised if people Hindu call Muslims as nyamabraya subs or relatives of Muslims. This term represents the fraternal relationship that is long enough between Hindu-Islam constructed through kinship ties based on blood relationships through cross-breeding different religions and cultures. despite initial between lead to conflict in the family, but it is usually able to be addressed by each family for the happiness of a child. This principle affirms that religious and cultural differences aren't a barrier to living in harmony and a milestone in upholding the values of tolerance toward others (interview Hambali: July 2016, community leaders Kampung Kusamba).

Values of multiculturalism formed since the past can't be separated from daily life activities as politics being played by a second entity of HinduMuslim communities. Since the first community of Muslim immigrants who arrive in Kusamba viewpoint on its own to maintain existence in the majority, they will make adaptation and acculturation to the local culture with honor and respect, not shy or exclusive themselves in religion, culture and the environment. It became the basis for the harmonization of relations inter build community.

The pattern of adaptation and acculturation and religion made by the two entities community groups are reflected in the behavior and activities such as megibung (eating together), metetulung, and ngejot. Social interactions are built by the community to uphold these values is to assist each other in preparing metetulung customary or religious ceremonies without being asked (mesuaka), but on its own consciousness and not favoritism. Ngejot tradition is a tradition in which people in Kampung Islam and Hinduism have a custom event by inviting the public or to express our gratitude to each other to deliver food. While culture megibung done by the people of Kampung Kusamba in the form of a circular sitting area Kusamba mosque itself. This activity is held every year on the eve of the day rayalslam (Eid al-Fitr and Eid al-Adha) with the aim to strengthen the brotherly relations and preserve the values of multiculturalism.

In order to maintain the values of multiculturalism, hometown village Kusamba not free of conflict, but also have experienced conflict. In general, the conflict-shaped tension as a result of disputes or conflicts between young fellow a neighbor. For example fights between groups of youths who originated from trivial issues, like drinking that causes drunk and making a scene. But this tension can be completed by the characters and the village of indigenous villages Kusamba. Traditional authorities and community leaders working to resolve issues that occur both in rural areas and villages Kusamba to give a positive impression of the existence of the village with all harmonization that has been built through the past.

\section{CONCLUSION}

The practice of multiculturalism in daily life politics by both the object of study namely Kampung Jawa and Kampung Kusamba basically supported by the historical background of the same, namely the Kingdom of acceleration and the Kingdom Gelgel an active role in instilling the value of multiculturalism then influential in the formation of attitudes and behavior later in life to maintain and memeilihara these values through customs and religious activities. In the tradition of the indigenous peoples a role model for a king will always be respected and upheld. second, the support of migrant communities with the ability of the management of diversity and perspective in building and maintaining social connections made through the adaptation and aklturasi culture. Finally, the values of multiculturalism can be achieved if the two entities community groups to support each other respect and 
appreciate each activity group. To uphold the principle of fraternity.

\section{REFERENCES}

Hadiz. Vedi, "Localising Power in Post Authoritarion Indonesia" Stanford University Press;USA, 2010.

Salim HS. Hairus, "Build Pluralism From Below", LKIS; Yogyakarta, 2007.

Nasikun, "Indonesia social System" Raja Grafindo Persada;Jakarta, 2004.

Parimantra, I Gede dkk, "Crescent on The Island of the gods; Traces of Islamic Villages in Kusamba Bali", editor by AAGN Ari Dwipayana

Huma Printing and Desain Graphic; Yogyakarta, 2012.

BPS, "Bali in Figures" 2015 